\title{
Review \\ Variation, Modification and Engineering of Lipid A in Endotoxin of Gram-Negative Bacteria
}

\author{
Kazuyoshi Kawahara
}

Citation: Kawahara, K. Variation, Modification and Engineering of Lipid A in Endotoxin of Gram-Negative Bacteria. Int. J. Mol. Sci. 2021, 22, 2281. https://doi.org/ $10.3390 /$ ijms 22052281

Academic Editor: Hiroshi Tamura

Received: 19 January 2021

Accepted: 22 February 2021

Published: 25 February 2021

Publisher's Note: MDPI stays neutral with regard to jurisdictional claims in published maps and institutional affiliations.

Copyright: (C) 2021 by the author. Licensee MDPI, Basel, Switzerland. This article is an open access article distributed under the terms and conditions of the Creative Commons Attribution (CC BY) license (https:// creativecommons.org/licenses/by/ $4.0 /)$.
Department of Biosciences, College of Science and Engineering, Kanto Gakuin University, Yokohama, Kanagawa 236-8501, Japan; kawahara@kanto-gakuin.ac.jp

\begin{abstract}
Lipid A of Gram-negative bacteria is known to represent a central role for the immunological activity of endotoxin. Chemical structure and biosynthetic pathways as well as specific receptors on phagocytic cells had been clarified by the beginning of the 21st century. Although the lipid A of enterobacteria including Escherichia coli share a common structure, other Gram-negative bacteria belonging to various classes of the phylum Proteobacteria and other taxonomical groups show wide variety of lipid A structure with relatively decreased endotoxic activity compared to that of E. coli. The structural diversity is produced from the difference of chain length of 3-hydroxy fatty acids and non-hydroxy fatty acids linked to their hydroxyl groups. In some bacteria, glucosamine in the backbone is substituted by another amino sugar, or phosphate groups bound to the backbone are modified. The variation of structure is also introduced by the enzymes that can modify electrostatic charges or acylation profiles of lipid A during or after its synthesis. Furthermore, lipid A structure can be artificially modified or engineered by the disruption and introduction of biosynthetic genes especially those of acyltransferases. These technologies may produce novel vaccine adjuvants or antagonistic drugs derived from endotoxin in the future.
\end{abstract}

Keywords: lipopolysaccharide; lipid A; endotoxin; chemical structure; fatty acid; engineering

\section{Introduction}

Although the term "endotoxin" implies a toxin produced by bacteria, it has another biochemical name, "lipopolysaccharide". Both terms properly suggest its immunological activities and function as a cell surface component of most Gram-negative bacteria that protect bacterial cells from a harsh outside environment. The lipopolysaccharide (LPS) of enterobacteria including Escherichia coli, and that of many other bacteria, consists of three distinct portions. The $\mathrm{O}$-antigenic polysaccharide is an antigenic polymer with wide variety of structure, and the core-oligosaccharide is composed of hexoses, hexosamines, L-glycero-D-manno-heptose, and 3-deoxy-D-manno-octulosonic acid (Kdo) that links the core and lipid A portions. Lipid A works as a lipid anchor to the outer membrane, and represents a central role for the endotoxic activity (Figure 1) [1]. In the present review, the history of endotoxin study, especially the establishment of the chemical structure of lipid A, and the discovery of a receptor specific to lipid A are summarized first. The variation of lipid A structure in relation to bacterial taxonomy is then described, followed by the modification of lipid A structure by genes of its biosynthetic enzymes. 


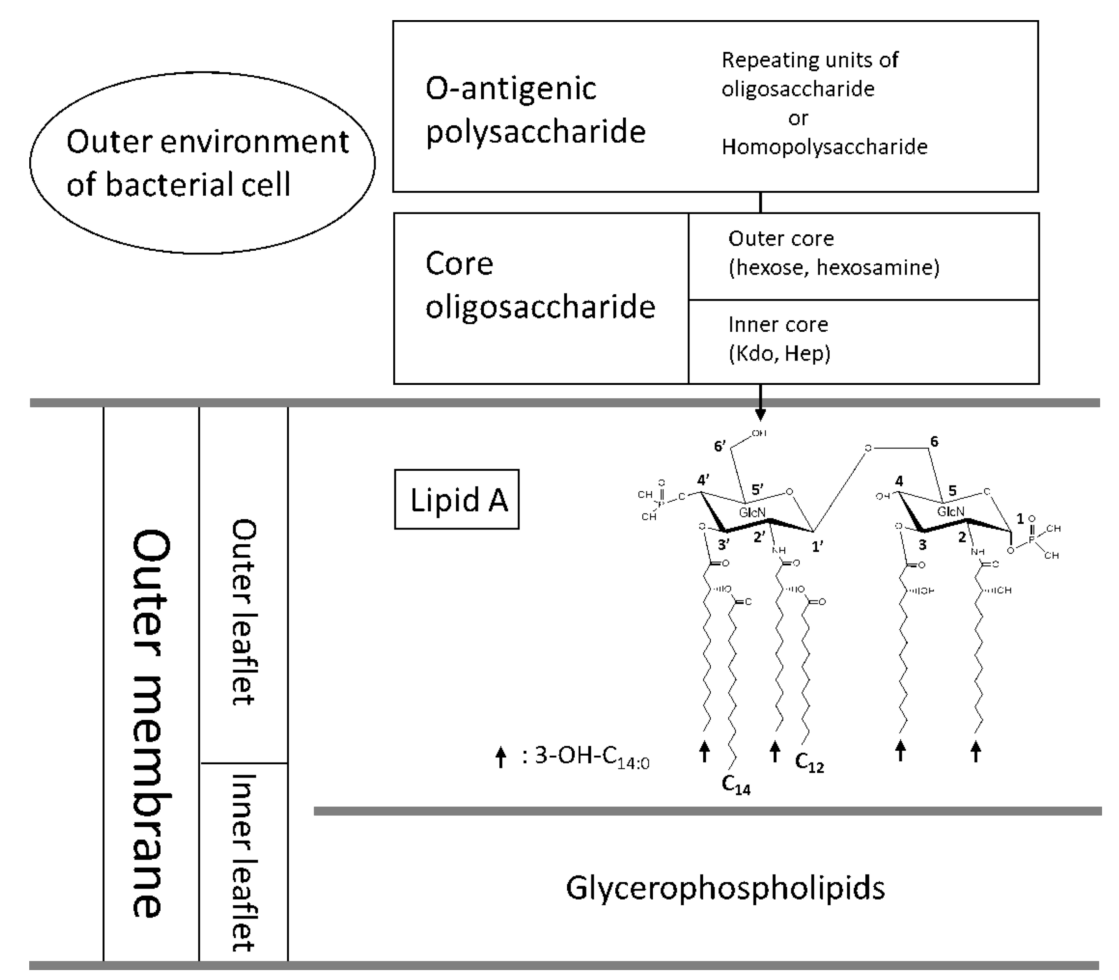

Figure 1. Schematic elucidation of outer membrane and chemical structure of lipid A region with the numbering of carbon atoms in the glucosamine-disaccharide backbone.

\section{Confirmation of Lipid A Structure and Discovery of a Lipid A-Specific Receptor}

The study of endotoxin was started by R. Pfeiffer at the end of the 19th century [2] during the study of Vibrio cholerae pathogenicity by R. Koch. The term "lipopolysaccharide", abbreviated as LPS, was first used by Shear in the study using Serratia marcescens [3]. Despite these early studies, we had to wait for confirmation of the chemical structure of lipid A and its central role in endotoxin activity in the 1980s when the structure of E. coli-type lipid A was chemically synthesized by Shiba, Kusumoto, and their colleagues at Osaka University $[4,5]$. These results were achieved by the close collaboration with Lüderitz, Galanos, Rietschel, and many other German researchers who had elaborated the extraction methods and accumulated experimental data on endotoxin [6-8]. At about the same time, the biosynthetic pathways of lipid A and the lipid A-Kdo region were intensively investigated by Raetz and his collaborators in USA [9], and lipid A was chemically and biochemically elucidated. Figure 1 shows the structure of $E$. coli lipid A, which represents the most immunologically active form among lipid A molecules from various Gramnegative bacteria.

Even after lipid A was chemically clarified, receptors of immune cells that recognize lipid A to induce immunological activity were kept mysterious. In 1990, the function of CD14 expressed on the plasma membrane of macrophages was reported, and mechanisms of binding with the aid of an LPS-binding protein (LBP) were investigated [10]. However, the search for the final receptor on phagocytic cells continued, and finally in 1998, just after the Toll receptor of Drosophila was discovered [11], the transmembrane leucine-rich protein, Toll-like receptor 4 (TLR4), was identified as a receptor specific to endotoxin (lipid A) [12]. TLR4 functions with a specific protein MD-2 to recognize lipid A, and transduces the binding information through protein kinases to NF- $\mathrm{kB}$ and other transcription factors that induce expression of pro-inflammatory cytokine genes such as IL-1 $\beta$, IL-6, or TNF- $\alpha$ in phagocytic cells $[13,14]$. We can therefore realize that the history of endotoxin research started in the 19th century, and the platform of knowledge necessary for further applicational study had been established at the beginning of the 21st century. 


\section{Diversity of Lipid A Structure in Various Taxonomic Groups of Gram-Negative Bacteria}

Gram-negative bacteria generally have a cell surface structure with cytoplasmic and outer membranes, and most of them, but not all, have LPS with a polar oligosaccharide region and lipid A as an anchor on the outer leaflet of the outer membrane. However, LPSs or lipid As that exhibit strong immunological activity are limited to bacteria of certain taxonomical groups, whereas many others have LPS with little immunological activity compared to that of E. coli and taxonomically related bacteria.

It is widely known that the most active lipid A recognized by TLR4 on dendritic cells and macrophages is "E. coli-type" lipid A (Figure 1) [1]. Most of the members of the family Enterobacteriaceae in the class $\gamma$-Proteobacteria share a principle lipid A structure consisting of a $\beta 1,6$-linked glucosamine (GlcN) dimer backbone, phosphate groups at the 1 and $4^{\prime}$ positions of the backbone, and four molecules of 3-hydroxymyristic acid (3-OH- $\left.\mathrm{C}_{14: 0}\right)$ linked to the 2, 3, 2' and $3^{\prime}$ positions of the backbone (see Figure 1 for numbering of carbon atoms in the backbone). The non-hydroxy fatty acids esterifying the hydroxyl groups of 3-OH- $\mathrm{C}_{14: 0}$ linked to the distal (non-reducing) GlcN have, to some extent, diversity among genera. Klebsiella pneumoniae produces lipid A with myristic acid $\left(\mathrm{C}_{14: 0}\right)$ at 3$\mathrm{OH}-\mathrm{C}_{14: 0}$ residues linked to the $2^{\prime}$ and $3^{\prime}$ positions in addition to the E. coli-type lipid A $[15,16]$. Yersinia pestis and Y. pseudotuberculosis substitute the hydroxyl group of 3-OH$\mathrm{C}_{14: 0}$ at the $2^{\prime}$ position with palmitoleic acid $\left(\mathrm{C}_{16: 1}\right)$ and that at the $3^{\prime}$ position with lauric acid $\left(\mathrm{C}_{12: 0}\right)$ at lower growth temperatures $\left(25-27^{\circ} \mathrm{C}\right)$. These fatty acids are nevertheless absent at $37^{\circ} \mathrm{C}$, the body temperature of humans and other mammals (Figure 2) [17,18]. Yersinia enterocolitica also shows the temperature-dependent lipid A modification, but the acylation profile is different from the above two species of this genus [18,19]. Salmonella enterica strains as well as other members of enterobacteria possess the pagP gene, which expresses an acyltransferase that can transfer palmitic acid $\left(\mathrm{C}_{16: 0}\right)$ to the hydroxyl group of 3-OH- $\mathrm{C}_{14: 0}$ at the 2 position of the backbone to produce hepta-acylated lipid A [20]. This conversion of lipid A acylation is believed to confer resistance of the bacterium against bactericidal agents such as defensins and LL-37 in phagocytic cells or the ability to survive in certain harsh environments [21]. Another popular group in $\gamma$-Proteobacteria is the family Pseudomonadaceae. Pseudomonas aeruginosa and taxonomically related bacteria contain lipid A with fatty acids of shorter carbon chains [22,23]. The 2 and $2^{\prime}$ positions of the backbone are substituted by 3-hydroxylauric acid (3-OH- $\left.\mathrm{C}_{12: 0}\right)$, whereas the 3 and $3^{\prime}$ positions are substituted (but not fully) by 3-hydroxycapric acid (3-OH- $\left.\mathrm{C}_{10: 0}\right)$. The hydroxyl groups of two 3-OH- $\mathrm{C}_{12: 0}$ residues are acylated by $\mathrm{C}_{12: 0}$ or 2-hydroxylauric acid (2-OH$\mathrm{C}_{12: 0}$ ). The latter fatty acid is formed by the oxygenation [24], which is described later in Section 4. Species of the genus Legionella form a phylogenetic cluster apart from the group containing Enterobacteriaceae and Pseudomonadaceae. This taxonomic distance is reflected by structural differences of lipid A. Legionella pneumophila, a causative agent of lethal pneumonia, has a lipid A with a backbone composed of a 2,3-diamino-2,3-dideoxy-glucose (GlcN3N) disaccharide, amide-linked fatty acids of 14-22 carbon atoms, and long-chain fatty acids such as 27-oxo-fatty acid with 28 carbon atoms ester-linked to iso- $C_{14: 0}$ at the $3^{\prime}$ position [25]. The presence of this distinct long-chain fatty acid suggests a relation with the family Rhizobiaceae in the class $\alpha$-Proteobacteria as described later in this section. 
$25^{\circ} \mathrm{C} \sim 27^{\circ} \mathrm{C}$

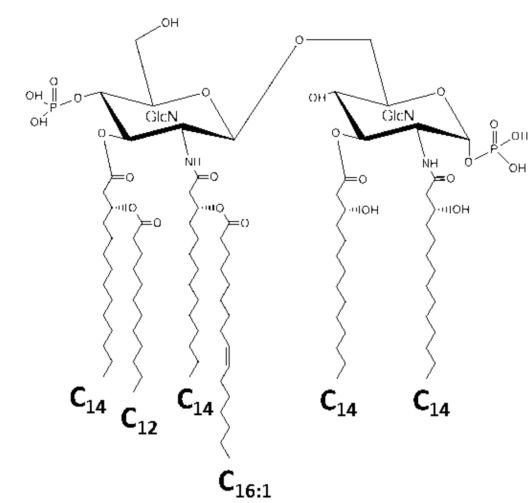

$37^{\circ} \mathrm{C}$

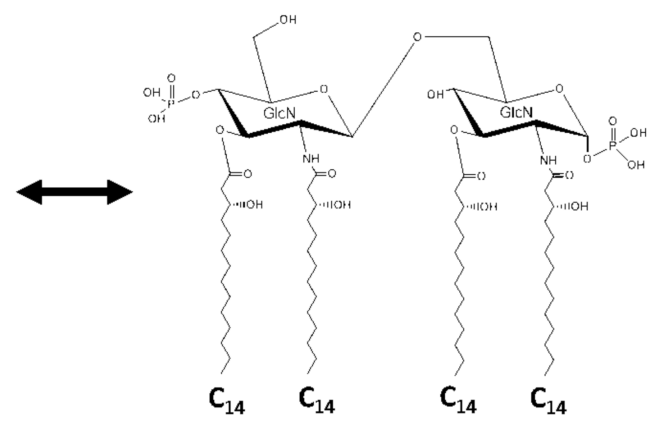

Figure 2. Structural conversion of Yersinia pestis lipid A by growth temperature $\left(25 \sim 27^{\circ} \mathrm{C}\right.$ : environmental temperature, $37^{\circ} \mathrm{C}$ : human body temperature).

The chain length of 3-hydroxy-fatty acids also shows a wide variety among species in the class $\beta$-Proteobacteria. The plant pathogen Burkholderia cepacia has a lipid A with 3-hydroxypalmitic acid (3-OH- $\left.\mathrm{C}_{16: 0}\right)$ at the 2 and $2^{\prime}$ positions, and one of them at the $2^{\prime}$ position is substituted by $\mathrm{C}_{14: 0}$. The 3 and $3^{\prime}$ positions are substituted by the common 3-OH-C $14: 0$ (Figure 3a) [26,27]. The causative agent of melioidosis, B. pseudomallei, has a similar substitution pattern of fatty acids in its lipid A [28,29]. Bordetella pertussis, a causative agent of whooping cough, is also a member of this class. The lipid A of this pathogen and related bacteria has been intensively studied by several groups including that of Caroff et al. in France [30-32]. This lipid A contains 3-OH- $\mathrm{C}_{10: 0}$ at the 3 position of the backbone, and the $2,2^{\prime}$, and $3^{\prime}$ positions are substituted by $3-\mathrm{OH}-\mathrm{C}_{14: 0}$, one of which bound at the $2^{\prime}$ position is substituted by $\mathrm{C}_{14: 0}$, representing a rather asymmetric lipid A structure. Modification of this lipid A is described in Section 5. Another member of $\beta$-Proteobacteria, Comamonas testosteroni, a resident of soil and water environments, has a lipid A of a symmetric structure with only a shorter 3-hydroxy fatty acid, 3-OH- $\mathrm{C}_{10: 0}$, at all of the $2,2^{\prime}, 3$, and $3^{\prime}$ positions, and the hydroxyl groups of those at the 2 and $2^{\prime}$ positions are substituted by $C_{14: 0}$ and $C_{12: 0}$, respectively (Figure $3 b$ ) [33]. Neisseria meningitidis also has a symmetric lipid A with 3-OH-C $\mathrm{C}_{12: 0}$ at the 3 and $3^{\prime}$ positions and $3-\mathrm{OH}-\mathrm{C}_{14: 0}$ esterified with $\mathrm{C}_{12: 0}$ at the 2 and $2^{\prime}$ positions [34].

a:

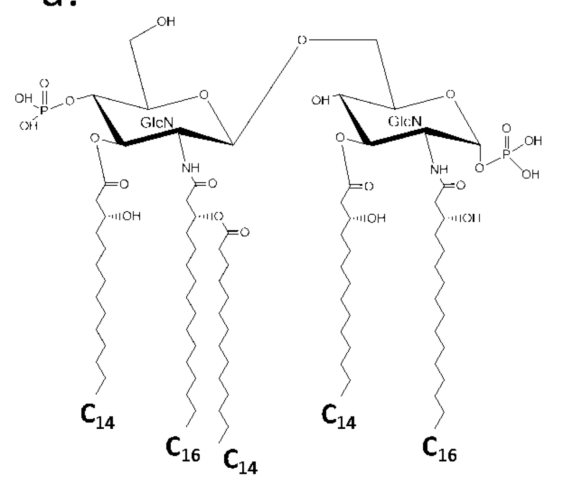

b:

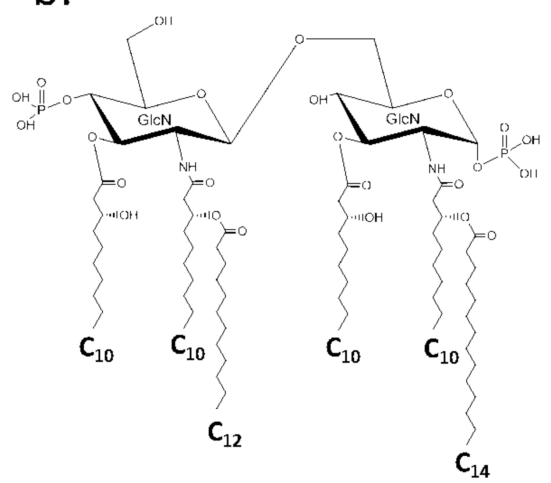

Figure 3. Chemical structure of lipid A from Burkholderia cepacia (a) and Comamonas testosteroni (b).

Helicobacter pylori is a member of the class $\varepsilon$-Proteobacteria, and a known cause of chronic gastritis. Its lipid A is composed of a reduced number of fatty acids [35,36]. It contains 3-hydroxy fatty acids with 16 and 18 carbon atoms, one of which at the $2^{\prime}$ position is substituted by stearic acid $\left(\mathrm{C}_{18: 0}\right)$. The 1 position of proximal (reducing end) $\mathrm{GlcN}$ is 
substituted by phosphate as other lipid A molecules, but the $4^{\prime}$ position of distal GlcN is unsubstituted. The predominant lipid A molecule is tetraacylated, but Suda et al. reported an even less acylated lipid A of this pathogen [37]. Campylobacter jejuni is also a member of $\varepsilon$-Proteobacteria, and its lipid A has a backbone composed of GlcN3N and GlcN as distal and proximal sugars, respectively. Although the sugar backbone is different from that of a usual lipid A, the chain lengths of 3-hydroxy fatty acids at the 2, 2', 3, and $3^{\prime}$ positions are identical to those of E. coli, and two 3-OH- $\mathrm{C}_{14: 0}$ molecules at the distal sugar are ester linked by $C_{16: 0}$ (Figure $4 b$ ) [38,39]. It should be noted that the transfer of $C_{16: 0}$ was reported to occur first to 3-OH-C $14: 0$ bound to the $3^{\prime}$ position of GlcN3N by the transferase LpxJ, followed by the second transfer of $\mathrm{C}_{16: 0}$ to $3-\mathrm{OH}-\mathrm{C}_{14: 0}$ of the $2^{\prime}$ position by another transferase LpxL (Figure $4 \mathrm{~b}$ ). This order of acylation is different from that of E. coli (Figure 4a), but is commonly found among the genera Helicobacter and Campylobacter [40].

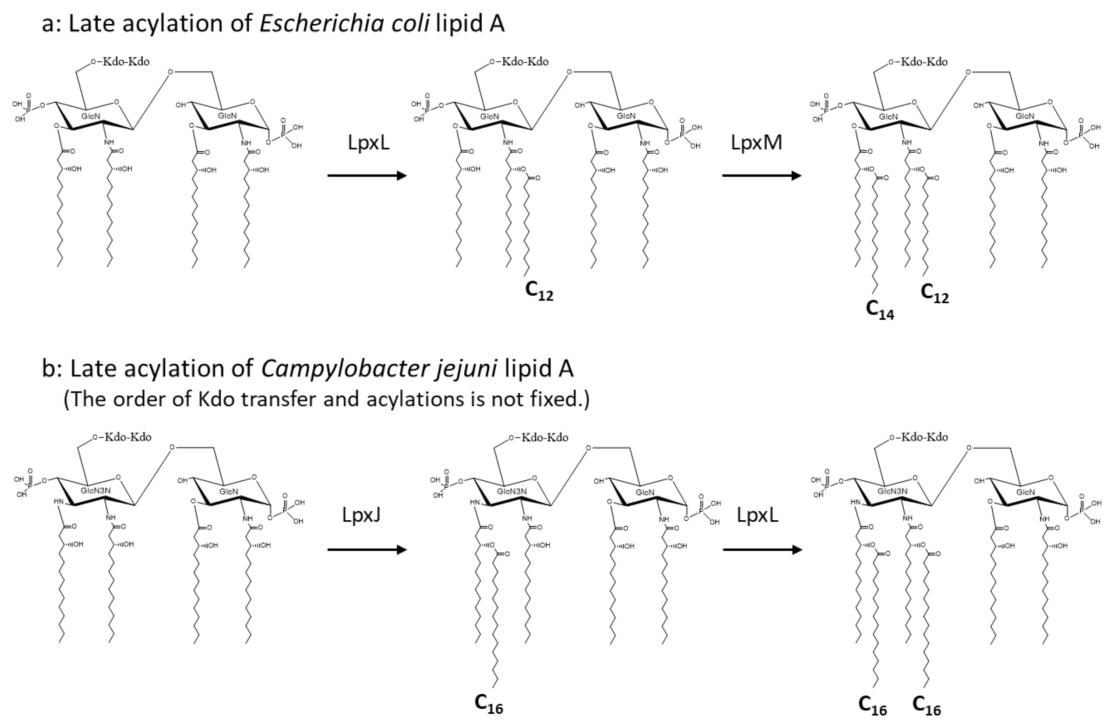

Figure 4. Acylation to form acyloxyacyl structure at the late stage of lipid A biosynthesis of Escherichia coli (a) and Campylobacter jejuni (b).

A group of bacteria that shows great structural variety of lipid A in the phylum Proteobacteria is the class $\alpha$-Proteobacteria. A photosynthetic bacterium, Rhodobacter sphaeroides has a lipid A with 3-OH- $\mathrm{C}_{14: 0}$ at the 2 and $2^{\prime}$ positions and 3-OH- $\mathrm{C}_{10: 0}$ at the 3 and $3^{\prime}$ positions, and 3-OH- $\mathrm{C}_{14: 0}$ at the $2^{\prime}$ position is substituted by tetradecenoic acid $\left(\mathrm{C}_{14: 1}\right)$ (Figure 5a) [41,42]. This lipid A is the model for the lipid A antagonist Eritoran, which was developed by Eisai Co. as a drug for severe sepsis (Figure 5b) [43,44]. Lipid A of the nodule-forming and $\mathrm{N}_{2}$-fixing bacterium, Rhizobium legminosarum, lacks phosphate groups at both the 1 and $4^{\prime}$ positions of the backbone, and galacturonic acid substitutes the $4^{\prime}$ position to supply a negative charge to this lipid A. It contains 27-hydroxyoctacosanoic acid (27-OH- $\left.\mathrm{C}_{28: 0}\right)$ with a 3-hydroxybutyrate ester linked to the 27-OH-group [45,46]. A similar lipid A structure with very long fatty acids and hopanoid was also found in Bradyrhizobium strains [47]. Acetobacter species, acetate-forming bacteria that are popular in the food industry, belong to $\alpha$-Proteobacteria as well. The lipid A of A. pasteurianus was recently investigated, and some features common with those of Rhizobium and Bradyrhizobium species were elucidated (Figure 6) [48,49]. This lipid A lacks phosphate, and the backbone is substituted by glucuronic acid and mannose at the 1 and $4^{\prime}$ positions, respectively. The backbone contains GlcN3N as a distal sugar, which was also found in Bradyrhizobium lipid A. Interestingly, the lipid A of A. pasteurianus links to the core oligosaccharide through D-glycero-D-talo-octulosonic acid (Ko) [48], which was first found in Acinetobacter LPS [50], and then in other species [51-53]. This sugar is deduced to stabilize the acid-labile linkage between lipid A and the core to adjust to acidic growth conditions. The class $\alpha$-Proteobacteria 
also contains obligate intracellular parasites, Rickettsia species. Unexpectedly, the lipid A of Rickettsia typhi conserves the basic structure similar to that of E. coli, although the fatty acids are longer $[54,55]$. It contains $3-\mathrm{OH}-\mathrm{C}_{16: 0}$ as amide linked fatty acids at the 2 and $2^{\prime}$ positions, $3-\mathrm{OH}-\mathrm{C}_{14: 0}$ as ester linked fatty acids at the 3 and $3^{\prime}$ positions, and $\mathrm{C}_{16: 0}$ linked to 3-hydroxy fatty acids at the distal GlcN. Among many unique taxonomic groups in the class $\alpha$-Proteobacteria, the families Sphingomonadaceae and Erythrobacteriaceae need to be described here, because members of these families are known to lack LPS, and instead, glycosphingolipids are present [56,57]. These glycosphingolipids contain glucuronic acid or galacturonic acid linked to ceramide, and exhibit immunostimulatory activity through activation of natural killer T-cells [58].
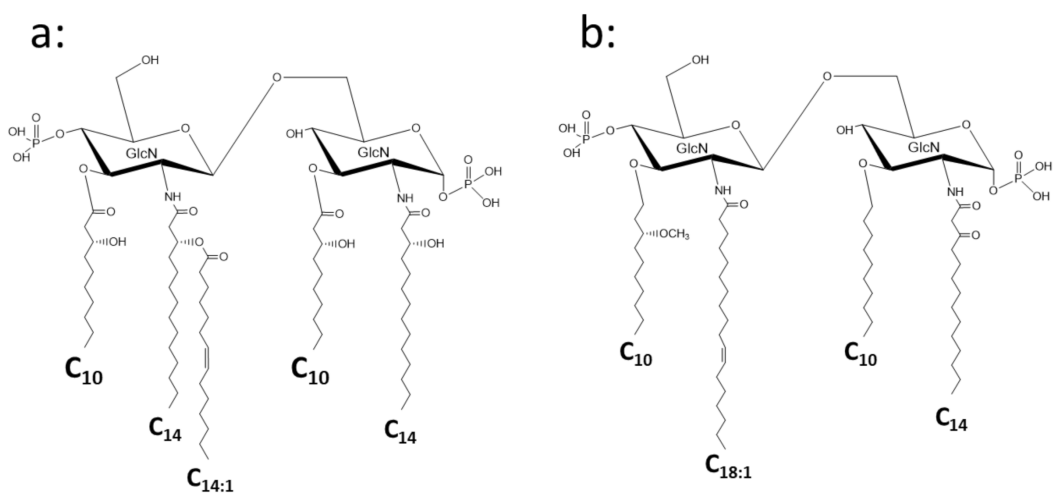

Figure 5. Chemical structure of Rhodobacter sphaeroides lipid A (a) and Eritoran (b) developed as an antagonist of endotoxin based on the structure of $R$. sphaeroides lipid A.

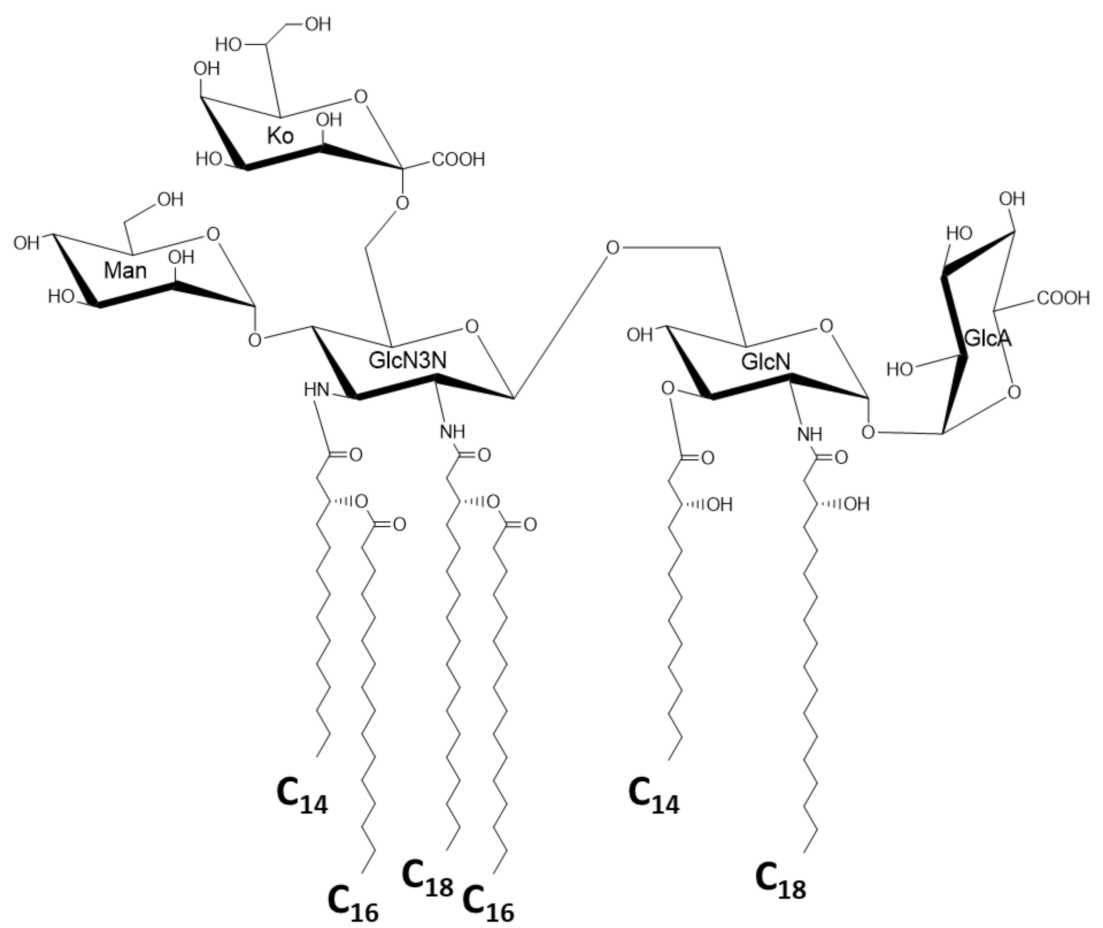

Figure 6. Chemical structure of Acetobacter pasteurianus lipid A with the sugar component (Ko) of the core oligosaccharide at the $6^{\prime}$ position of the backbone.

The phylum Bacteroidetes is independent from the large phylum Proteobacteria, but the basic structure of lipid A is conserved by most of the members of this phylum. The lipid A of Bacteroides fragilis has a sugar backbone identical to that of the family Enterobacteriaceae, and is similarly acylated, although the chain length and molecular species of fatty acids are 
different. The $2^{\prime}$ position is substituted by 3-hydroxy iso-heptadecanoic acid (3-OH-iso$\mathrm{C}_{17: 0}$ ) with its hydroxyl group esterified with iso-pentadecanoic acid (iso- $\mathrm{C}_{15: 0}$ ). The 2, 3, and $3^{\prime}$ positions are substituted by $3-\mathrm{OH}-\mathrm{C}_{16: 0}$, 3-hydroxypentadecanoic acid (3-OH- $\mathrm{C}_{15: 0}$ ), and 3-OH- $\mathrm{C}_{16: 0}$, respectively, whereas the $4^{\prime}$ position is not phosphorylated [59]. Another member of this phylum is the family Porphyromonadaceae. Prophyromonas gingivalis is a causative agent of periodontal disease, but recently thought to be involved in many other diseases [60]. The lipid A is similar to that of $B$. fragilis. It partially lacks the phosphate group at the $4^{\prime}$ position, and is acylated by $3-\mathrm{OH}$-iso- $\mathrm{C}_{17: 0}$ at the 2 and $2^{\prime}$ positions. One of 3-OH-iso- $\mathrm{C}_{17: 0}$ bound to the $2^{\prime}$ position is substituted by $\mathrm{C}_{16: 0}$. The 3 and $3^{\prime}$ positions are substituted by 3-OH- $\mathrm{C}_{16: 0}$ and 3-hydroxy iso-pentadecanoic acid (3-OH-iso- $\mathrm{C}_{15: 0}$ ), respectively [61,62]. Recently, one species of this phylum, Aureispira marina, isolated from marine debris [63], was found to contain only trace amounts of 3-hydroxy fatty acids and a large amount of ceramide, suggesting a lack of LPS in this bacterium [64].

It is not easy to summarize the correlation between lipid A structure and bacterial taxonomy as the diversity of the structure is very wide, and the structural difference does not always correspond to the taxonomic distance, as we see the similarity of lipid A of the families Bacteroidaceae and Enterobacteriacea that belong to the different phylums. Nevertheless, informative tables presenting bacteria-lipid A structure relationships are found in some review articles $[65,66]$.

\section{Structural Modification of Lipid A after the Synthesis of LPS}

After lipid A-core region is synthesized at the inner surface of the cytoplasmic membrane, it is transported to the outer surface of the membrane [67]. At this stage, the phosphate groups at the 1 and $4^{\prime}$ positions of the backbone may be modified by positively charged hydrophilic molecules. Colistin-resistant strains of E. coli and other enteric bacteria have lipid A with phosphoethanolamine bound to one of the phosphate groups in the lipid A molecule $[68,69]$. The plasmid-encoded gene $m c r-1$ and its variant genes are responsible for the transferases. Additionally, aminoarabinose transferase can transfer 4 -aminoarabinose (Ara4N) to the phosphate groups [70]. These enzymes are widely distributed among species of Enterobacteriaceae and also other families of Proteobacteria [71,72]. Phosphoethanolamine and Ara $4 \mathrm{~N}$ can neutralize the negative charges of the phosphate groups and disturb the action of cationic antibiotics or antibacterial agents. However, these substitutions do not directly affect the recognition of lipid A by TLR4 and MD-2 [73].

On the contrary, modifications of the fatty acid profile greatly influence the binding of lipid A to TLR4/MD-2, and they can occur even after mature LPS is transported to the outer membrane. $\mathrm{C}_{16: 0}$ transferase, known as PagP in Salmonella species, resides in the outer membrane, and transfers $\mathrm{C}_{16: 0}$ to the hydroxyl group of 3-OH- $\mathrm{C}_{14: 0}$, which is linked to the amino group of the 2 position, to form hepta-acylated lipid A [21]. Enzymes homologous to PagP are widely present among species of the family Enterobacteriaceae and other species of Proteobacteria [74]. Salmonella species also have a modifying enzyme known as PagL, which liberates 3-OH- $\mathrm{C}_{14: 0}$ from the 3 position of lipid A [75]. Homologous enzymes were found in a variety of species in Proteobacteria [76]. Another deacylating enzyme LpxR is present in enterohaemorrhagic E. coli, Salmonella, and several other bacteria [77,78]. The enzyme can liberate 3-OH- $\mathrm{C}_{14: 0}$ at the $3^{\prime}$ position together with the non-hydroxy fatty acids bound to it. These acylating and deacylating modifications certainly affect the hydrophobicity, the conformation, and the affinity between lipid A and its receptor TLR4, and reduce the immunoactivity of lipid A or the lipid A-containing LPS [79,80]. By these modifications described above, lipid A can change the electrostatic charge and hydrophobicity, and also the rigidity and fluidity of the outer membrane to adjust bacterial cells to the living environment or that of infection.

Different from modification by acylation or deacylation, Salmonella enterica has an enzyme that hydroxylates $\mathrm{C}_{14: 0}$ at the distal GlcN of lipid A to 2-hydroxymyristic acid $\left(2-\mathrm{OH}-\mathrm{C}_{14: 0}\right)$ [81]. This hydroxylation of fatty acid in lipid A was suggested to be an oxygenation reaction using ${ }^{18} \mathrm{O}_{2}$ in an early study of Pseudomonas lipid A [82], and genetically 
proved by using Salmonella $[81,83]$. The substrate of this hydroxylation was assumed to be fully acylated Kdo-Kdo-lipid A, indicating that this enzyme is also one of those that can work after the synthesis of mature LPS. 2-Hydroxy fatty acids are major components of lipid A molecules from aerobic species such as Pseudomonas, Chromobacterium, Acinetobacter, Bordetella, and many other genera [84]. In the case of Pseudomonas aeruginosa and Acinetobacter baumannii, the hydroxylation was reported to have some relation with the pathogenicity and infectivity [24,85], but no influence on the membrane integrity. However, the physiological meaning of this hydroxylation should be further investigated if we consider the presence of 2-hydroxy fatty acids in many non-pathogenic bacteria.

Most of lipid A-modifying enzymes described in this section are known to be regulated by the two component systems, PhoP-PhoQ and PmrA-PmrB [86]. The environmental conditions such as $\mathrm{pH}$ and concentration of divalent cations or nutrition influence the lipid A structure and also the survival of bacteria through these two-component systems.

\section{Construction of Novel Lipid A Structure by Genetic Engineering}

Until the early 1980s, little was known about the biosynthetic pathways of lipid A. Codeveloped with structural studies, all of the synthetic pathways had been elucidated in a few decades, and the genes for the enzymes involved were cloned [87,88]. With the accumulation of this knowledge, we now have a possibility to create a novel lipid A structures with a desirable immunological activity. However, simple cloning or manipulation of genes does not always produce a novel structure, because each enzyme has substrate specificity, and foreign intermediates may not be recognized as substrates for the next reaction, resulting in very low yield of product. Nevertheless, several successful examples are found in recent studies.

Li et al. [89] constructed mutant strains of E. coli with different acylation patterns using the $p a g L$ gene and previously reported mutant strains of acyltransferases [90,91]. Needham et al. [92] generated library of strains by the combination of two E. coli mutant strains and genes of phosphatases from Francisella tularensis and the acyl chain-modifying enzymes described above in this review. They demonstrated that variety of lipid A molecules with graded TLR4-dependent cytokine responses can be produced.

Bainbridge et al. [93] constructed an E. coli strain defective of the lpxL gene and harboring a cloned Bacteroides $\mathrm{C}_{16: 0}$ transferase gene. The recombinant $E$. coli strain produced lipid A with $\mathrm{C}_{16: 0}$ instead of $\mathrm{C}_{12: 0}$ as the acyl chain bound to 3-OH- $\mathrm{C}_{14: 0}$ at the $2^{\prime}$ position. This strain was used to investigate the effects of intestinal microbiota for inflammatory bowel disease [94].

Our group also constructed an E. coli mutant that lacks $l p x L$ and the $p a g P$-homologous gene ( $\operatorname{crc} A)$, and used it for lipid A modification [95]. The mutant strain still has $\operatorname{lp} x M\left(\mathrm{C}_{14: 0}\right.$ transferase gene), but transfers little amount of $\mathrm{C}_{14: 0}$ to $3-\mathrm{OH}-\mathrm{C}_{14: 0}$ at the $3^{\prime}$ position. With the plasmid-encoded pagP from Salmonella, the E. coli strain produced the lipid A with only one acyloxyacyl structure with $\mathrm{C}_{16: 0}$ bound to $3-\mathrm{OH}-\mathrm{C}_{14: 0}$ at the 2 position in proximal GlcN. Interestingly, the IL-6-inducing activity of the LPS from this strain was only slightly recovered, although the growth rate and resistance to polymyxin $\mathrm{B}$ became nearly normal. When lpxL2, a $\mathrm{C}_{14: 0}$ transferase gene of Klebsiella pneumoniae [96], was introduced instead of pagP, the strain produced lipid A with two $\mathrm{C}_{14: 0}$ molecules bound to $3-\mathrm{OH}-\mathrm{C}_{14: 0}$ at the $2^{\prime}$ and $3^{\prime}$ positions. The LPS from this strain showed IL-6-inducing activity comparable to that of the wild-type strain [97].

Arenas et al. [98] engineered Bordetella pertussis to shorten the acyl chain length in the lipid A structure. Introduction of the $l p x A$ gene for a 3-OH- $\mathrm{C}_{10: 0}$ transferase from $P$. aeruginosa changed the asymmetric structure of the molecule to symmetric by the substitution of 3-OH- $\mathrm{C}_{14: 0}$ with 3-OH-C $\mathrm{C}_{10: 0}$ (Figure 7). Similarly, introduction of the lpxD gene for a 3-OH- $\mathrm{C}_{12: 0}$ transferase from the same bacterium changed the fatty acids at the 2 and $2^{\prime}$ positions to 3-OH- $\mathrm{C}_{12: 0}$ (Figure 7). The LPS of the recombinant B. pertussis strain exhibited lower endotoxic activity, suggesting the possibility of a new whole-cell pertussis vaccine with reduced pyrogenicity. They also succeeded to introduce the $\operatorname{lp} x L$ gene $\left(\mathrm{C}_{12: 0}\right.$ 
transferase gene) from Neisseria meningitidis and the $l p x L$ gene ( $C_{16: 0}$ transferase gene) from Porphyromonas gingivalis, and substituted ester-linked $C_{14: 0}$ by $C_{12: 0}$ and $C_{16: 0}$, respectively.

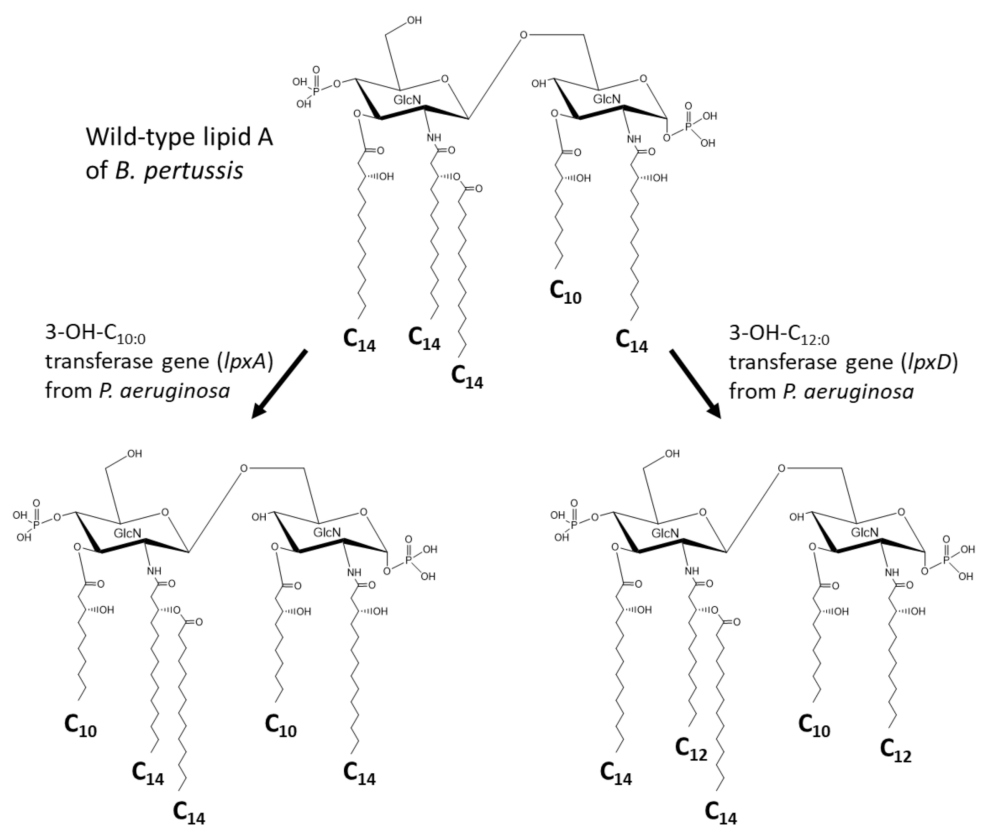

Figure 7. Engineering of Bordetella pertussis lipid A using acyltransferase genes from Pseudomonas aeruginosa.

These reported examples demonstrate that artificial modification or engineering of lipid A structure is possible if we utilize appropriate acyltransferase genes, and other genes for lipid A synthesis, if necessary, cloned from foreign bacterial strains. Mutant strains defective of one or more acyltransferase genes and lacking an acyloxyacyl structure in lipid A are useful tools for lipid A engineering. Such mutant strains can be constructed as reported by several groups including ours [91-93,95,99], because the acyloxyacyl structure is not essential for the function of lipid A in the outer membrane, although in most cases the mutant strains grow slowly and are susceptible to antibacterial drugs. Additionally, the reports on engineered B. pertussis strains $[98,100]$ showed the possibility that fatty acids directly bound to the sugar backbone can also be substituted if we choose the proper combination of acyltransferase genes and host bacteria.

\section{Closing Remarks}

As demonstrated in this review, variations of lipid A in various Gram-negative bacteria are unlimited. Novel lipid A structures will be found and reported further in the future, which would provide us models for the structural modification. Lipid A engineering is attractive because it may produce lipid A molecules with expected or unexpected immunological activity, and may improve lipid A-derived vaccine adjuvants [101-103] that are highly required at present for the new generation vaccine against emerging infectious diseases. Moreover, it may help to develop the lipid A-antagonistic drugs such as Eritoran (Figure $5 b$ ) to rescue the septic shock caused by bacterial infections. Thus, the diversity of microorganisms and their genes for lipid A biosynthesis will give us the possibility to create new drugs derived from endotoxin.

Funding: This research received no external funding.

Institutional Review Board Statement: Not applicable.

Informed Consent Statement: Not applicable.

Data Availability Statement: Not Applicable. 
Acknowledgments: The author would like to thank Hiroshi Tamura for providing the opportunity to prepare this manuscript.

Conflicts of Interest: The author declares no conflict of interest.

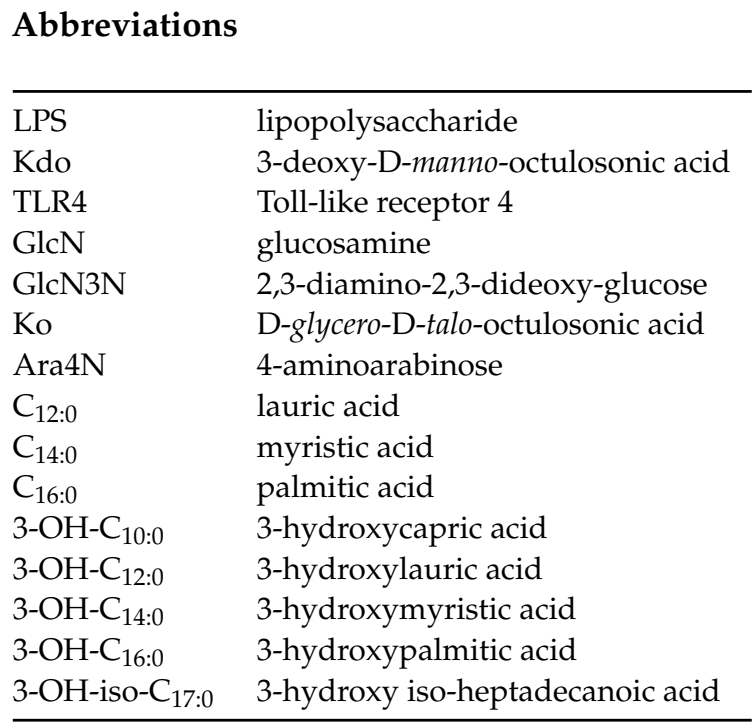

\section{References}

1. Alexander, C.; Rietschel, E.T. Bacterial lipopolysaccharides and innate immunity. J. Endotoxin Res. 2001, 7, 167-202. [CrossRef] [PubMed]

2. Pfeiffer, R. Untersuchungen über das Choleragift. Z. Hygiene 1892, 11, 393-412. [CrossRef]

3. Shear, M.J.; Turner, F.C.; Perrault, A.; Shovelton, T. Chemical treatment of tumors. V. Isolation of the hemorrhage-producing fraction from Serratia marcescens (Bacillus prodigiosus) culture filtrate. J. Natl. Cancer Inst. 1943, 4, 81-97. [CrossRef]

4. Imoto, M.; Yoshimura, H.; Kusumoto, S.; Shiba, T. Total synthesis of lipid A, active principle of bacterial endotoxin. Proc. Jpn. Acad. Ser. B 1984, 60, 285-288. [CrossRef]

5. Kawahara, K. Synthetic chemistry with friendships that unveiled the long-lasting mystery of lipid A. Innate Immun. 2019, 25, 203-212. [CrossRef] [PubMed]

6. Lüderitz, O.; Freudenberg, M.A.; Galanos, C.; Lehman, V.; Rietschel, E.T.; Shaw, D.W. Lipopolysaccharide of Gram-negative bacteria. In Microbial Membrane Lipids; Razin; Razin, C.S., Rottem, S., Eds.; Academic Press: New York, NY, USA, 1982; Volume 17, pp. 79-151.

7. Rietschel, E.T.; Wollenweber, H.-W.; Brade, H.; Zähringer, U.; Lindner, B.; Seydel, U.; Bradaczek, H.; Barnickel, G.; Labischinski, H.; Giesbrecht, P. Structure and conformation of the lipid A component of lipopolysaccharides. In Handbook of Endotoxin; Chemistry of Endotoxin; Rietschel, E.T., Ed.; Elsevier: Amsterdam, The Netherlands, 1984; Volume 1, pp. 187-220.

8. Galanos, C.; Lüderitz, O.; Rietschel, E.T.; Westphal, O.; Brade, H.; Brade, L.; Freudenberg, M.; Schade, U.; Imoto, M.; Yoshimura, H.; et al. Synthetic and natural Escherichia coli free lipid A express identical endotoxic activities. Eur. J. Biochem. 1985, 148, 1-5. [CrossRef]

9. Raetz, C.R.H. Biochemistry of endotoxins. Annu. Rev. Biochem. 1990, 59, 129-170. [CrossRef] [PubMed]

10. Wright, S.D.; Ramos, R.A.; Tobias, P.S.; Ulevitch, R.J.; Mathison, J.C. CD14, a receptor for complexes of lipopolysaccharide (LPS) and LPS binding protein. Science 1990, 249, 1431-1433. [CrossRef]

11. Lemaitre, B.; Nicolas, E.; Michaut, L.; Reichhart, J.-M.; Hoffmann, J.A. The dorsoventral regulatory gene cassette spätzle/Toll/cactus controls the potent antifungal response in Drosophila adults. Cell 1996, 86, 973-983. [CrossRef]

12. Poltorak, A.; He, X.; Smirnova, I.; Liu, M.-Y.; Van Huffel, C.; Du, X.; Birdwell, D.; Alejos, E.; Silva, M.; Galanos, C.; et al. Defective LPS signaling in C3H/HeJ and C57BL/10ScCr mice: Mutations in Tlr4 gene. Science 1998, 282, 2085-2088. [CrossRef]

13. Shimazu, R.; Akashi, S.; Ogata, H.; Nagai, Y.; Fukudome, K.; Miyake, K.; Kimoto, M. MD-2, a molecule that confers lipopolysaccharide responsiveness on Toll-like receptor 4. J. Exp. Med. 1999, 189, 1777-1782. [CrossRef] [PubMed]

14. Miyake, K. Roles for accessory molecules in microbial recognition by Toll-like receptors. J. Endotoxin Res. 2006, 12, 195-204. [CrossRef]

15. Clements, A.; Tull, D.; Jenney, A.W.; Farn, J.L.; Kim, S.-H.; Bishop, R.E.; McPhee, J.B.; Hancock, R.E.W.; Hartland, E.L.; Pearse, M.J.; et al. Secondary acylation of Klebsiella pneumoniae lipopolysaccharide contributes to sensitivity to anti-bacterial peptides. J. Biol. Chem. 2007, 282, 15569-15577. [CrossRef] [PubMed]

16. Mills, G.; Dumigan, A.; Kidd, T.; Hobley, L.; Bengoechea, J.A. Identification and characterization of two Klebsiella pneumoniae lpxL lipid A late acyltransferases and their role in virulence. Infect. Immunol. 2017, 85, e00068-e17. [CrossRef] 
17. Kawahara, K.; Tsukano, H.; Watanabe, H.; Lindner, B.; Matsuura, M. Modification of the structure and activity of lipid A in Yersinia pestis lipopolysaccharide by growth temperature. Infect. Immun. 2002, 70, 4092-4098. [CrossRef] [PubMed]

18. Rebeil, R.; Ernst, R.K.; Gowen, B.B.; Miller, S.I.; Hinnebusch, B.J. Variation in lipid A structure in the pathogenic yersiniae. Mol. Microbiol. 2004, 52, 1363-1373. [CrossRef]

19. Pérez-Gutiérrez, C.; Llobet, E.; Llompart, C.M.; Reinés, M.; Bengoechea, J.A. Role of lipid A acylation in Yersinia enterocolitica virulence. Infect. Immun. 2010, 78, 2768-2781. [CrossRef] [PubMed]

20. Bishop, R.E.; Gibbons, H.S.; Guina, T.; Trent, M.S.; Miller, S.I.; Raetz, C.R.H. Transfer of palmitate from phospholipids to lipid A in outer membranes of Gram-negative bacteria. EMBO J. 2000, 19, 5071-5080. [CrossRef]

21. Bishop, R.E. The lipid A palmitoyltransferase PagP: Molecular mechanisms and role in bacterial pathogenesis. Mol. Microbiol. 2005, 57, 900-912. [CrossRef]

22. Kulshin, V.A.; Zähringer, U.; Lindner, B.; Jager, K.-E.; Dmitriev, B.A.; Rietschel, E.T. Structural characterization of the lipid A component of Pseudomonas aeruginosa wild-type and rough mutant lipopolysaccharides. Eur. J. Biochem. 1991, 198, 697-704. [CrossRef]

23. Froning, M.; Helmer, P.O.; Hayen, H. Identification and structural characterization of lipid A from Escherichia coli, Pesudomonas putida and Pseudomonas taiwanensis using liquid chromatography coupled to high-resolution tandem mass spectrometry. Rapid Commun. Mass Specrom. 2020, 34, e8897.

24. Sciuto, A.L.; Cervoni, M.; Stefanelli, R.; Spinnato, M.C.; Di Giamberardino, A.; Mancone, C.; Imperi, F. Genetic basis and physiological effects of lipid A hydroxylation in Pseudomonas aeruginosa PAO1. Pathogens 2019, 8, 291. [CrossRef]

25. Zähringer, U.; Knirel, Y.A.; Lindner, B.; Helbig, J.H.; Sonesson, A.; Marre, R.; Rietschel, E.T. The lipopolysaccharide of Legionella pneumophila serogroup 1 (strain Philadelphia 1): Chemical structure and biological significance. Prog. Clin. Boil. Res. 1995, 392, 113-139.

26. De Soyza, A.; Silipo, A.; Lanzetta, R.; Govan, J.R.; Molinaro, A. Chemical and biological features of Burkholderia cepacia complex lipopolysaccharides. Innate Immun. 2008, 14, 127-144. [CrossRef]

27. Mohamed, Y.F.; Hamad, M.; Ortega, X.P.; Valvano, M.A. The LpxL acyltransferase is required for normal growth and pentaacylation of lipid A in Burkholderia cenocepacia. Mol. Microbiol. 2017, 104, 144-162. [CrossRef] [PubMed]

28. Kawahara, K.; Dejsirilert, S.; Danbara, H.; Ezaki, T. Extraction and characterization of lipopolysaccharide from Pseudomonas pseudomallei. FEMS Microbiol. Lett. 1992, 75, 129-133. [CrossRef]

29. Sengyee, S.; Yoon, S.H.; Paksanont, S.; Yimthin, T.; Wuthiekanun, V.; Limmathurotsakul, D.; West, T.E.; Ernst, R.K.; Chantratita, N. Comprehensive analysis of clinical Burkholderia pseudomallei isolates demonstrates conservation of unique lipid A structure and TLR4-dependent innate immune activation. Plos Negl. Trop. Dis. 2018, 12, e0006287. [CrossRef]

30. MacArthur, I.; Mann, P.B.; Harvill, E.T.; Preston, A. IEIIS Meeting minireview: Bordetella evolution: Lipid A and Toll-like receptor 4. J. Endotoxin Res. 2007, 13, 243-247. [CrossRef]

31. Caroff, M.; Deprun, C.; Richards, J.C.; Karibian, D. Structural characterization of the lipid A of Bordetella pertussis 1414 endotoxin. J. Bacteriol. 1994, 176, 5156-5159. [CrossRef] [PubMed]

32. Bouchez, V.; AlBitar-Nehmé, S.; Novikov, A.; Guiso, N.; Caroff, M. Bordetella holmesii: Lipid A structures and corresponding genomic sequences comparison in three clinical isolates and the reference strain ATCC 51541. Int. J. Mol. Sci. 2017, 18, 1080. [CrossRef] [PubMed]

33. Iida, T.; Haishima, Y.; Tanaka, A.; Nishiyama, K.; Saito, S.; Tanamoto, K. Chemical structure of lipid A isolated from Comamonas testosteroni lipopolysaccharide. Eur. J. Biochem. 1996, 237, 468-475. [CrossRef]

34. Kulshin, A.V.; Zähringer, U.; Lindner, B.; Frasch, C.E.; Tsai, C.M.; Dmitriev, B.A.; Rietschel, E.T. Structural characterization of the lipid A component of pathogenic Neisseria meningitidis. J. Bacteriol. 1992, 174, 1793-1800. [CrossRef]

35. Moran, A.P.; Lindner, B.; Walsh, E.J. Structural characterization of the lipid A component of Helicobacter pylori rough- and smooth-form lipopolysaccharides. J. Bacteriol. 1997, 179, 6453-6463. [CrossRef]

36. Li, H.; Liao, T.; Debowski, A.W.; Tang, H.; Nilsson, H.-O.; Stubbs, K.A.; Marshall, B.J.; Benghezal, M. Lipopolysaccharide structure and biosynthesis in Helicobacter pylori. Helicobacter 2016, 21, 445-461. [CrossRef] [PubMed]

37. Suda, Y.; Ogawa, T.; Kashihara, W.; Oikawa, M.; Shimoyama, T.; Hayashi, T.; Tamura, T.; Kusumoto, S. Chemical structure of lipid A from Helicobacter pylori strain 206-1 lipopolysaccharide. J. Biochem. 1997, 121, 1129-1133. [CrossRef] [PubMed]

38. Moran, A.P.; Zähringer, U.; Seydel, U.; Scholz, D.; Stutz, P.; Rietschel, E.T. Structural analysis of the lipid A component of Campylobacter jejuni CCUG 10936 (serotype O:2) lipopolysaccharide. Description of a lipid A containing a hybrid backbone of 2-amino-2-deoxy-D-glucose and 2,3-diamino-2,3-dideoxy-D-glucose. Eur. J. Biochem. 1991, 198, 459-469. [CrossRef] [PubMed]

39. van Mourik, A.; Steeghs, L.; van Laar, J.; Meiring, H.D.; Hamstra, H.-J.; van Putten, J.P.M.; Wösten, M.M.S.M. Altered linkage of hydroxyacyl chains in lipid A of Campylobacter jejuni reduces TLR4 activation and antimicrobial resistance. J. Biol. Chem. 2010, 285, 15828-15836. [CrossRef]

40. Rubin, E.J.; O’Brien, J.P.; Ivanov, P.L.; Brodbelt, J.S.; Trent, M.S. Identification of a broad family of lipid A late acyltransferases with non-canonical substrate specificity. Mol. Microbiol. 2014, 91, 887-899. [CrossRef]

41. Salimath, P.V.; Weckesser, J.; Strittmatter, W.; Mayer, H. Structural studies on the non-toxic lipid A from Rhodopseudomonas sphaeroides ATCC 17023. Eur. J. Biochem. 1983, 136, 195-200. [CrossRef] [PubMed]

42. Qureshi, N.; Honovich, J.P.; Hara, H.; Cotter, R.J.; Takayama, K. Location of fatty acids in lipid A obtained from lipopolysaccharide of Rhodopseudomonas sphaeroides ATCC 17023. J. Biol. Chem. 1988, 263, 5502-5504. [CrossRef] 
43. Rossignol, D.P.; Lynn, M. TLR4 antagonists for endotoxemia and beyond. Curr. Opin. Investig. Drugs 2005, 6, 496-502. [PubMed]

44. Deguchi, A.; Tomita, T.; Ohto, U.; Takemura, K.; Kitao, A.; Akashi-Takamura, S.; Miyake, K.; Maru, Y. Eritoran inhibits S100A8mediated TLR4/MD-2 activation and tumor growth by changing the immune microenvironment. Oncogene 2016, 35, 1445-1456. [CrossRef] [PubMed]

45. Bhat, U.; Forsberg, L.; Carlson, R. Structure of lipid A component of Rhizobium leguminosarum bv. phaseoli lipopolysaccharide. Unique nonphosphorylated lipid A containing 2-amino-2-deoxygluconate, galacturonate, and glucosamine. J. Biol. Chem. 1994, 269, 14402-14410. [CrossRef]

46. Bourassa, D.V.; Kannenberg, E.L.; Sherrier, D.J.; Buhr, R.J.; Carlson, R.W. The lipopolysaccharide lipid A long-chain fatty acid is important for Rhizobium legminosarum growth and stress adaptation in free-living and nodule environments. Mol. Plant Microbe Interact. 2017, 30, 161-175. [CrossRef] [PubMed]

47. Busset, N.; Di Lorenzo, F.; Palimigiano, A.; Sturiale, L.; Gressent, F.; Fardoux, J.; Gully, D.; Chaintreuil, C.; Molinaro, A.; Silipo, A.; et al. The very long chain fatty acid $\left(\mathrm{C}_{26}: 25 \mathrm{OH}\right)$ linked to the lipid A is important for the fitness of the photosynthetic Bradyrhizobium strain ORS278 and the establishment of a successful symbiosis with Aeschynomene legumes. Front. Microbiol. 2017, 8, 1821. [CrossRef]

48. Hashimoto, M.; Ozono, M.; Furuyashiki, M.; Baba, R.; Hashiguchi, S.; Suda, Y.; Fukase, K.; Fujimoto, Y. Characterization of a novel D-glycero-D-talo-oct-2-ulosonic acid-substituted lipid A moiety in the lipopolysaccharide produced by the acetic acid bacterium Acetobacter pasteurianus NBRC 3283. J. Biol. Chem. 2016, 291, 21184-21194. [CrossRef] [PubMed]

49. Pallach, M.; Di Lorenzo, F.; Facchini, F.A.; Gully, D.; Giraud, E.; Peri, F.; Duda, K.A.; Molinaro, A.; Silipo, A. Structure and inflammatory activity of the LPS isolated from Acetobacter pasteurianus CIP103108. Int. J. Biol. Macromol. 2018, 119, 1027-1035. [CrossRef]

50. Kawahara, K.; Brade, H.; Rietschel, E.T.; Zähringer, U. Studies on the chemical structure of the core-lipid A region of the lipopolysaccharide of Acinetobacter calcoaceticus NCTC 10305. Detection of a new 2-octulosonic acid interlinking the core oligosaccharide and lipid A component. Eur. J. Biochem. 1987, 163, 489-495. [CrossRef] [PubMed]

51. Isshiki, Y.; Zähringer, U.; Kawahara, K. Structure of the core-oligosaccharide with a characteristic D-glycero- $\alpha$-D-talo-oct-2ulosylonate-(2 $\rightarrow 4)$-3-deoxy-D-manno-oct-2-ulosonate $[\alpha-\mathrm{Ko}-(2 \rightarrow 4)$-Kdo] disaccharide in the lipopolysaccharide from Burkholderia cepacia. Carbohydr. Res. 2003, 338, 2659-2666. [CrossRef] [PubMed]

52. Coderch, N.; Piqué, N.; Lindner, B.; Abitiu, N.; Merino, S.; Izquierdo, L.; Jimenez, N.; Tomás, J.M.; Holst, O.; Regué, M. Genetic and structural characterization of the core region of the lipopolysaccharide from Serratia marcescens N28b (serovar O4). J. Bacteriol. 2004, 186, 978-988. [CrossRef] [PubMed]

53. Chung, H.S.; Raetz, C.R.H. Dioxygeneses in Burkholderia ambifaria and Yersinia pestis that hydroxylate the outer Kdo unit of lipopolysaccharide. Proc. Natl. Acad. Sci. USA 2011, 108, 510-515. [CrossRef] [PubMed]

54. Fodorová, M.; Vadovič, P.; Toman, R. Structural features of lipid A of Rickettsia typhi. Acta Virol. 2011, 55, 31-44. [CrossRef] [PubMed]

55. Guillotte, M.L.; Gillespie, J.J.; Chandler, C.E.; Rahman, M.S.; Ernst, R.K.; Azad, A.F. Rickettsia lipid A biosynthesis utilizes the late acyltransferase LpxJ for secondary fatty acid addition. J. Bacteriol. 2018, 200, e00334-18. [CrossRef] [PubMed]

56. Kawahara, K.; Seydel, U.; Matsuura, M.; Danbara, H.; Rietschel, E.T.; Zähringer, U. Chemical structure of glycosphingolipids isolated from Sphingomonas paucimobilis. FEBS Lett. 1991, 292, 107-110. [CrossRef]

57. Kawahara, K.; Kuraishi, H.; Zähringer, U. Chemical structure and function of glycosphingolipids of Sphingomonas spp and their distribution among members of the $\alpha-4$ subclass of Proteobacteria. J. Ind. Microbiol. Biotechnol. 1999, 23, 408-413. [CrossRef]

58. Kinjo, Y.; Wu, D.; Kim, G.; Xing, G.-W.; Poles, M.A.; Ho, D.D.; Tsuji, M.; Kawahara, K.; Wong, C.-H.; Kronenberg, M. Recognition of bacterial glycosphingolipids by natural killer T cells. Nature 2005, 434, 520-525. [CrossRef] [PubMed]

59. Weintraub, A.; Zähringer, U.; Wollenweber, H.-W.; Seydel, U.; Rietschel, E.T. Structural characterization of the lipid A component of Bacterioides fragilis strain NCTC 9343 lipopolysaccharide. Eur. J. Biochem. 1989, 183, 425-431. [CrossRef]

60. Olsen, I.; Taubman, M.A.; Singhrao, S.K. Porphyromonas gingivalis suppresses adaptive immunity in periodontitis, atherosclerosis, and Alzheimer's disease. J. Oral Microbiol. 2016, 8, 33029. [CrossRef]

61. Ogawa, T. Chemical structure of lipid A from Porphyromonas (Bacteroides) gingivalis lipopolysaccharide. FEBS Lett. 1993, 332, 197-201. [CrossRef]

62. Kumada, H.; Haishima, Y.; Umemoto, T.; Tanamoto, K. Structural study on the free lipid A isolated from lipopolysaccharide of Porphyromonas gingivalis. J. Bacteriol. 1995, 177, 2098-2106. [CrossRef] [PubMed]

63. Hosoya, S.; Arunpairojana, V.; Suwannachart, C.; Kanjana-Opas, A.; Yokota, A. Aureispira marina gen. nov., sp. nov., a gliding, arachidonic acid-containing bacterium isolated from the southern coastline of Thailand. Int. J. Syst. Evol. Microbiol. 2006, 56, 2931-2935. [CrossRef] [PubMed]

64. Kawahara, K.; Iida, H.; Yokota, A. Detection of 2-hydroxy-fatty acids and 2-hydroxy-fatty acid-containing ceramides in a gliding marine bacterium Aureispira marina. J. Gen. Appl. Microbiol. 2021, in press.

65. Zähringer, U.; Lindner, B.; Rietschel, E.T. Chemical structure of lipid A: Recent advances in structural analysis of biologically active molecules. In Endotoxin in Health and Disease; Brade, H., Opal, S.M., Vogel, S.N., Morrison, D.C., Eds.; CRC Press: Boca Raton, FL, USA, 1999; pp. 93-114.

66. Kusumoto, S.; Hashimoto, M.; Kawahara, K. Structure and synthesis of lipid A. In Advances in Experimental Medicine and Biology; Lipid A in Cancer Therapy; Jeannin, J.-F., Ed.; Landes Bioscience: Austin, TX, USA, 2009; Volume 667, pp. 5-23. 
67. Whitfield, C.; Trent, M.S. Biosynthesis and export of bacterial lipopolysaccharides. Annu. Rev. Biochem. 2014, 83, 99-128. [CrossRef]

68. Liu, Y.-Y.; Wang, Y.; Walsh, T.R.; Yi, L.-X.; Zhang, R.; Spencer, J.; Doi, Y.; Tian, G.; Dong, B.; Huang, X.; et al. Emergence of plasmid-mediated colistin resistance mechanism MCR-1 in animals and human beings in China: A microbiological and molecular biological study. Lancet Infect. Dis. 2016, 16, 161-168. [CrossRef]

69. Gao, R.; Hu, Y.; Li, Z.; Sun, J.; Wang, Q.; Lin, J.; Ye, H.; Liu, F.; Srinivas, S.; Li, D.; et al. Dissemination and mechanism for the MCR-1 colistin resistance. PLoS Pathog. 2016, 12, e1005957. [CrossRef]

70. Trent, M.S.; Ribeiro, A.A.; Lin, S.; Cotter, R.J.; Raetz, C.R.H. An inner membrane enzyme in Salmonella and Escherichia coli that transfers 4-amino-4-deoxy-L-arabinose to lipid A: Induction on polymyxin-resistant mutants and role of a novel lipid-linked donor. J. Biol. Chem. 2001, 276, 43122-43131. [CrossRef] [PubMed]

71. Zhang, H.; Srinivas, S.; Xu, Y.; Wei, W.; Feng, Y. Genetic and biochemical mechanisms for bacterial lipid A modifiers associated with polymyxin resistance. Trends Biochem. Sci. 2019, 44, 973-988. [CrossRef] [PubMed]

72. Moffatt, J.H.; Harper, M.; Boyce, J.D. Mechanisms of polymyxin resistance. Adv. Exp. Med. Biol. 2019, 1145, 55-71. [CrossRef] [PubMed]

73. Park, B.S.; Song, D.H.; Kim, H.M.; Choi, B.-S.; Lee, H.; Lee, J.-O. The structural basis of lipopolysaccharide recognition by the TLR4-MD-2 complex. Nature 2009, 458, 1191-1195. [CrossRef]

74. Bishop, R.E.; Kim, S.-H.; El Zoeiby, A. Role of lipid A palmitoylation in bacterial pathogenesis. J. Endotoxin Res. 2005, 11, 174-180 [CrossRef]

75. Trent, M.S.; Pabich, W.; Raetz, C.R.H.; Miller, S.I. A PhoP/PhoQ-induced lipase (PagL) that catalyzes 3-O-deacylation of lipid A precursors in membranes of Salmonella typhimurium. J. Biol. Chem. 2001, 276, 9083-9092. [CrossRef]

76. Geurtsen, J.; Steeghs, L.; Ten Hove, J.; van der Ley, P.; Tommassen, J. Dissemination of lipid A deacylases (PagL) among Gram-negative bacteria: Identification of active-site histidine and serine residues. J. Biol. Chem. 2005, 280, 8248-8259. [CrossRef] [PubMed]

77. Reynolds, C.M.; Ribeiro, A.A.; McGrath, S.C.; Cotter, R.J.; Raetz, C.R.H.; Trent, M.S. An outer membrane enzyme encoded by Salmonella typhimurium lpxR that removes the $3^{\prime}$-acyloxyacyl moiety of lipid A. J. Biol. Chem. 2006, 281, 21974-21987. [CrossRef] [PubMed]

78. Ogawa, R.; Yen, H.; Kawasaki, K.; Tobe, T. Activation of $l p x R$ gene through enterohaemorrhagic Escherichia coli virulence regulators mediates lipid A modification to attenuate innate immune response. Cell Microbiol. 2018, 20, e12806. [CrossRef] [PubMed]

79. Kawasaki, K.; Ernst, R.K.; Miller, S.I. 3-O-deacylation of lipid A by PagL, a PhoP/PhoQ-regulated deacylase of Salmonella typhimurium, modulates signaling through Toll-like receptor 4. J. Biol. Chem. 2004, 279, 20044-20048. [CrossRef] [PubMed]

80. Matsuura, M.; Kawasaki, K.; Kawahara, K.; Mitsuyama, M. Evasion of human innate immunity without antagonizing TLR4 by mutant Salmonella enterica serovar Typhimurium having penta-acylated lipid A. Innate Immun. 2012, 18, 764-773. [CrossRef] [PubMed]

81. Gibbons, H.S.; Lin, S.; Cotter, R.J.; Raetz, C.R.H. Oxygen requirement for the biosynthesis of the S-2-hydroxymyristate moiety in Salmonella typhimurium lipid A. J. Biol. Chem. 2000, 275, 32940-32949. [CrossRef] [PubMed]

82. Kawahara, K.; Uchida, K.; Aida, K. Direct hydroxylation in the biosynthesis of hydroxy fatty acid in lipid A of Pseudomonas ovalis. Biochim. Biophys. Acta 1979, 572, 1-8.

83. Gibbons, H.S.; Reynolds, C.M.; Guan, Z.; Raetz, C.R.H. An inner membrane dioxygenase that generates the 2-hydroxymyristate moiety of Salmonella lipid A. Biochemistry 2008, 47, 2814-2825. [CrossRef] [PubMed]

84. Zähringer, U.; Lindner, B.; Rietschel, E.T. Molecular structure of lipid A, the endotoxic center of bacterial lipopolysaccharides. Adv. Carbohydr. Chem. Biochem. 1994, 50, 211-276.

85. Bartholomew, T.L.; Kidd, T.J.; Sá Pessoa, J.; Álvarez, R.C.; Bengoechea, J.A. 2-Hydroxylation of Acinetobacter baumannii lipid A contributes to virulence. Infect. Immun. 2019, 87, e00066-e19. [CrossRef] [PubMed]

86. Anandan, A.; Vrielink, A. Structure and function of lipid A-modifying enzymes. Ann. N. Y. Acad. Sci. 2020, 1459, 19-37. [CrossRef] [PubMed]

87. Raetz, C.R.H.; Whitfield, C. Lipopolysaccharide endotoxins. Annu. Rev. Biochem. 2002, 71, 635-700. [CrossRef]

88. Raetz, C.R.; Reynolds, C.M.; Trent, M.S.; Bishop, R.E. Lipid A modification systems in Gram-negative bacteria. Annu. Rev. Biochem. 2007, 76, 295-329. [CrossRef] [PubMed]

89. Li, Y.; Wang, Z.; Chen, J.; Ernst, R.K.; Wang, X. Influence of lipid A acylation pattern on membrane permeability and innate immune stimulation. Mar. Drugs 2013, 11, 3197-3208. [CrossRef]

90. Karow, M.; Georgopoulos, C. Isolation and characterization of the Escherichia coli msbB gene, a multicopy suppressor of null mutations in the high-temperature requirement gene htrB. J. Bacteriol. 1992, 174, 702-710. [CrossRef]

91. Vorachek-Warren, M.K.; Ramirez, S.; Cotter, R.J.; Raetz, C.R.H. A triple mutant of Escherichia coli lacking secondary acyl chains on lipid A. J. Biol. Chem. 2002, 277, 14194-14205. [CrossRef] [PubMed]

92. Needham, B.D.; Carroll, S.M.; Giles, D.K.; Georgiou, G.; Whiteley, M.; Trent, M.S. Modulating the innate immune response by combinatorial engineering of endotoxin. Proc. Natl. Acad. Sci. USA 2013, 110, 1464-1469. [CrossRef]

93. Bainbridge, B.W.; Coats, S.R.; Pham, T.-T.T.; Reife, R.A.; Darveau, R.P. Expression of a Porphyromonas gingivalis lipid A palmitylacyltransfease in Escherichia coli yields a chimeric lipid A with altered ability to stimulate interleulin-8 secretion. Cell Microbiol. 2006, 8, 120-129. [CrossRef] 
94. Gronbach, K.; Flade, I.; Holst, O.; Lindner, B.; Ruscheweyh, H.J.; Wittmann, A.; Menz, S.; Schwiertz, A.; Adam, P.; Stecher, B.; et al. Endotoxicity of lipopolysaccharide as a determinant of T-cell-mediated colitis induction in mice. Gastroenterology 2014, 146, 765-775. [CrossRef]

95. Sugawara, T.; Onoue, S.; Takimoto, H.; Kawahara, K. Modification of lipid A structure and activity by the introduction of palmitoyltransferase gene to the acyltransferase-knockout mutant of Escherichia coli. Microbiol. Immunol. 2018, 62, 497-506. [CrossRef] [PubMed]

96. Li, Y.; Yun, J.; Liu, L.; Li, Y.; Wang, X. Identification of two genes encoding for the late acyltransferase of lipid A in Klebsiella penumniae. Curr. Microbiol. 2016, 73, 732-738. [CrossRef] [PubMed]

97. Taniguchi, C.; Sugawara, T.; Onoue, S.; Kawahara, K. Structural modification of Escherichia coli lipid A by myristoyltransferase gene from Klebsiella pneumoniae. Microbiol. Immunol. 2019, 63, 334-337. [CrossRef]

98. Arenas, J.; Pupo, E.; Phielix, C.; David, D.; Zariri, A.; Zamyatina, A.; Tommassen, J.; van der Ley, P. Shortening the lipid A acyl chains of Bordetella pertussis enables depletion of lipopolysaccharide endotoxic activity. Vaccines 2020, 8, 594. [CrossRef] [PubMed]

99. Schilling, B.; Hunt, J.; Gibson, B.W.; Apicella, M.A. Site-specific acylation changes in the lipid A of Escherichia coli lpxL mutants grown at high temperatures. Innate Immun. 2014, 20, 269-282. [CrossRef]

100. Arenas, J.; Pupo, E.; de Jonge, E.; Pérez-Ortega, J.; Schaarschmidt, J.; van der Ley, P.; Tommassen, J. Substrate specificity of the pyrophosphohydrolase LpxH determines the asymmetry of Bordetella pertussis lipid A. J. Biol. Chem. 2019, 294, 7982-7989. [CrossRef]

101. Qureshi, N.; Takayama, K.; Ribi, E. Purification and structural determination of nontoxic lipid A obtained from the lipopolysaccharide of Salmonella typhimurium. J. Biol. Chem. 1982, 257, 11808-11815. [CrossRef]

102. Mitchell, T.C.; Casella, C.R. No pain no gain? Adjuvant effects of alum and monophosphoryl lipid A in pertussis and HPV vaccines. Curr. Opin. Immunol. 2017, 47, 17-25. [CrossRef] [PubMed]

103. Masoud, H. Novel adjuvants derived from attenuated lipopolysaccharides and lipid As of purple non-sulfur photosynthetic bacteria. Vaccine 2019, 37, 3472-3477. [CrossRef] [PubMed] 